\title{
Methane emission from a flooded rice field under pre-germinated system
}

\author{
Magda Aparecida de Lima ${ }^{*}$ (D) Rosana Faria Vieira ${ }^{1}$ (i) Rosa Toyoko Shiraishi Frighetto ${ }^{1}$ (iD \\ Alfredo José Barreto Luiz ${ }^{1}$ (D) Omar Vieira Villela ${ }^{2}$ (D)
}

\author{
${ }^{1}$ Empresa Brasileira de Pesquisa Agropecuária, Embrapa Meio Ambiente, 13820-000, Jaguariúna, SP, Brasil. E-mail: magda.lima@embrapa.br. \\ ${ }^{*}$ Corresponding author. \\ ${ }^{2}$ Agência Paulista de Tecnologia dos Agronegócios (APTA), Polo Regional Vale do Paraíba, Pindamonhangaba, SP, Brasil.
}

\begin{abstract}
Local greenhouse gas flow measurement studies have been encouraged at a global level as a subsidy for national and state inventories. This study aimed to evaluate the seasonal methane emission during the 2008/2009 harvest, from an irrigated rice plantation, under pre-germinated system, in the municipality of Tremembé, State of São Paulo, using the static chamber technique and gas chromatography. The study showed high seasonal emission of methane $\left(\mathrm{CH}_{4}\right)$ for the studied area, probably due to the long flooding period. It was estimated the $\mathrm{CH}$ emission factor (6.2 $\mathrm{kg} \mathrm{CH}_{4} \mathrm{ha}^{-1}$ dia $\left.^{-1}\right)$, the partial global warming potential ( $\mathrm{pGWP}, 26.2 \mathrm{Mg} \mathrm{CO}_{2}$ eq growing season ${ }^{-1}$ ha ${ }^{-1}$ ) and the yield-scaled pGWP (YpGWP, $3.9 \mathrm{~kg} \mathrm{CO}_{2}$ eq $\mathrm{kg}^{-1}$ grain).

Key words: flooded rice, pre-germinated system, methane.
\end{abstract}

Emissão de metano em área de arroz irrigado sob sistema pré-germinado

RESUMO: Estudos locais de mensuração de fluxos de gases de efeito estufa em sistemas agrícolas têm sido incentivados a nível global como base para subsidiar estimativas nacionais e estaduais de emissão. Este estudo objetivou quantificar a emissão sazonal de metano (CH em cultivo de arroz irrigado, sob sistema pré-germinado, no municipio de Tremembé, Estado de São Paulo, na safra de 2008/2009, utilizando o método de câmara estática e cromatografia gasosa. $\mathrm{O}$ estudo mostrou elevada emissão sazonal de $\mathrm{CH}_{4}$ para a área estudada, em função, provavelmente do longo periodo de inundação. Foi estimado o fator de emissão de $\mathrm{CH}_{4}\left(6,2 \mathrm{~kg} \mathrm{CH}_{4} \mathrm{ha}^{-1}\right.$ dia $\left.\mathrm{d}^{-1}\right)$, o potencial de aquecimento global parcial (PAGp, 26,2 $\mathrm{Mg} \mathrm{CO}_{2}$ eq estação de crescimento ${ }^{-1} \mathrm{ha}^{-1}$ ) e o PAGp escalonado pelo rendimento (R) de grãos (PAGpR, 3,9 kg CO eq $\left.\mathrm{kg}^{-1} \mathrm{grão}\right)$.

Palavras-chave: arroz irrigado por inundação, sistema pré-germinado, metano.

Cultivation of flooded rice produces methane $\left(\mathrm{CH}_{4}\right)$, a potent greenhouse gas. In Brazil, $\mathrm{CH}_{4}$ emission from rice cultivation was estimated to be $0.46 \mathrm{Tg} \mathrm{CH}_{4}$ in 2010 of a total of $12.42 \mathrm{Tg}$ from the agricultural sector (BRAZIL, 2016). Local $\mathrm{CH}_{4}$ measurement studies in flooded rice plantations have been carried out in different climatic regions, soils, and water and crop managements in the country (SILVA et al., 2011; ZSCHORNACK et al., 2011; MOTERLE et al., 2013; BAYER et al., 2014; LIMA et al., 2014; BAYER et al., 2015; ZSCHORNACK et al., 2016). However, few studies have been reported on rice production under pre-germinated system (LIMA et al., 2007; EBERHARDT et al., 2009), which is used in some regions of the country. The availability of data on $\mathrm{CH}_{4}$ emission factors is a key element in conducting national and regional greenhouse gas emission inventories. Thus, in order to contribute with databases on $\mathrm{CH}_{4}$ emission factors from flooded rice crop, the present study aimed to estimate the $\mathrm{CH}_{4}$ emission factor from this cultivation under the pre-germinated system in a tropical area in the southeastern Brazil. It was also evaluated the partial GWP ( $p$ GWP) and the yield-scaled $p$ GWP.

An on-farm experiment was carried out in the municipality of Tremembé, State of São Paulo, Brazil, situated at a latitude of $22^{\circ} 56^{\prime} 12^{\prime \prime} \mathrm{S}$ and longitude of $45^{\circ} 34^{\prime} 07^{\prime \prime} \mathrm{W}$ at a mean altitude of 580 meters. This municipality is one of the main rice producing areas of that state. The climate is of the Cwa type, characterized by an altitude tropical climate with rain in the summer and drought in the winter. Air temperature and rainfall during rice season were registered by an automatic meteorological station (Figure 1A). The soil is classified as Melanic Gleysoil (EMBRAPA, 2013), with the following physical and 


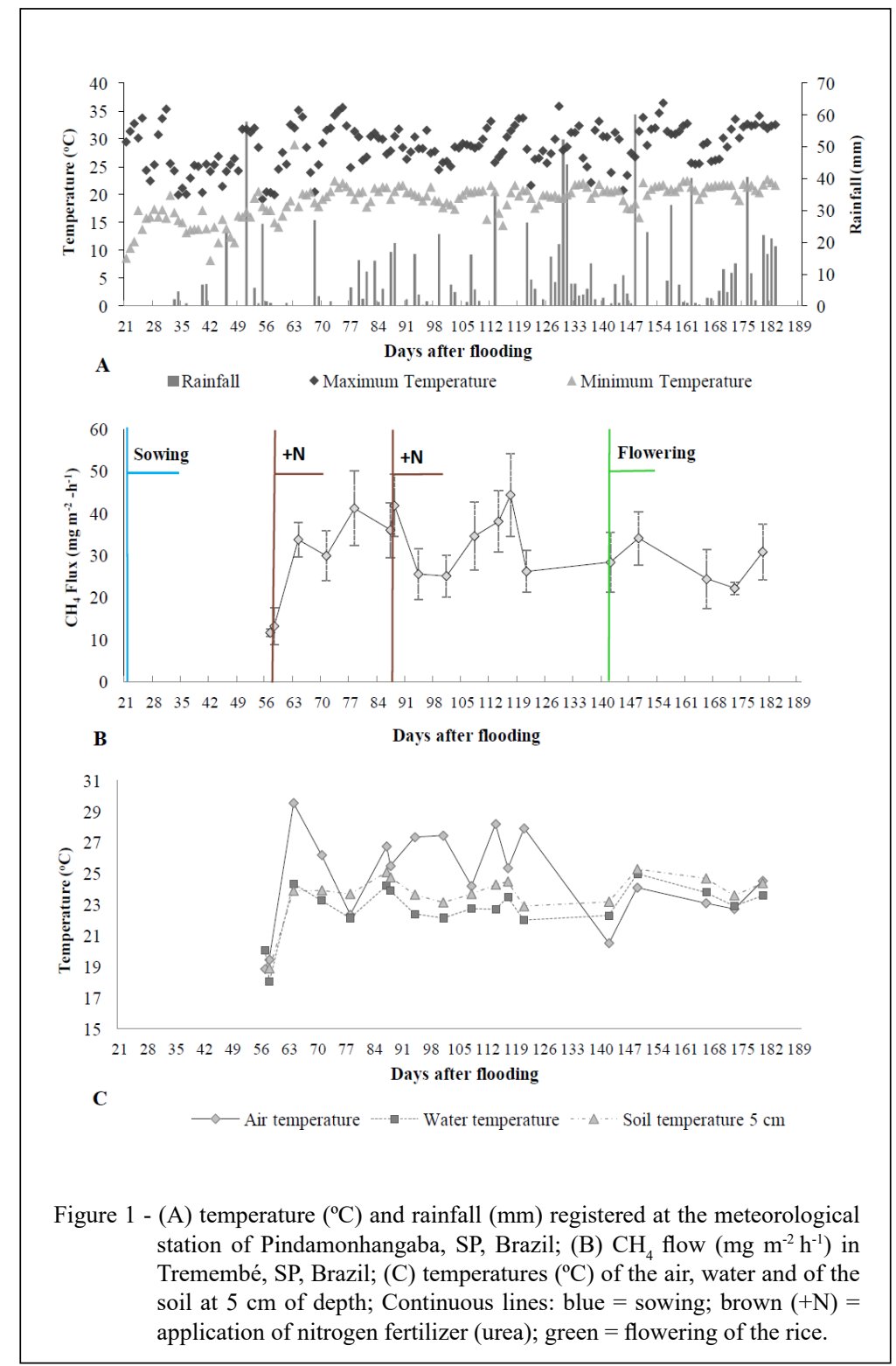

chemical characteristics at 0-20 cm depth: $41.4 \%$ sand, $36.0 \%$ silt and $22.6 \%$ clay; density: $1.31 \mathrm{~g} \mathrm{~cm}^{-3}$; total porosity: $48.91 \%$; $\mathrm{pH}$ in $\mathrm{H}_{2} \mathrm{O}=5.55$; total $\mathrm{C}=9.1$ $\mathrm{g} \mathrm{kg}^{-1}$; total $\mathrm{N}=0.88 \mathrm{~g} \mathrm{~kg}^{-1} ; \mathrm{P}=3.63 \mathrm{mg} \mathrm{dm}^{-3} ; \mathrm{K}, \mathrm{Ca}, \mathrm{Mg}$, $\mathrm{H}+\mathrm{Al}=0.27,1.09,0.53,3.35 \mathrm{cmol}_{\mathrm{c}} \mathrm{dm}^{-3}$, respectively, and $\mathrm{V}=37.6 \%$ (Silva, 2009). Total C (TC) and total $\mathrm{N}$ (TN) contents were determined using an elementary $\mathrm{C}$ and $\mathrm{N}$ analyzer (Truspec-Leco). The experiment was carried out under broadcast pre-germinated system, during the 2008/2009 harvest, with continuous water irrigation, and consisted of a single treatment with three repetitions in a one hectare block. This type of cultivation is characterized by the use of pre- germinated seeds in previously flooded soil. Straw from the previous crop was incorporated into the soil after harvesting. The soil was plowed three months in advance and flooded twenty days before sowing, which occurred on $02 / 09 / 2008$ with the emergency observed on $09 / 09 / 2008$. This previous flooding was due to control of the red rice. The long-cycle variety SCS 114 Andosan (140 days) was used with a seed density of $140 \mathrm{~kg}$ per hectare. After flooding of the soil and the initial development of the seedlings, the height of the floodwater was maintained at an average of $16 \mathrm{~cm}$. The agrochemical management was done according to regional technical recommendations. 
At 49 days after flooding (DAF) were applied the herbicides Ricer (150 mL), Basagran (2 L) and Ally $(10 \mathrm{~g})$, and with the insecticide Curbix $(200 \mathrm{~mL})$ and Vegetoil ( $1 \mathrm{~L})$. Covering fertilization was carried out twice, with the first at $58 \mathrm{DAF}$ and the second at $85 \mathrm{DAF}$, using the formulation $25-0-25(30 \mathrm{~kg} \mathrm{~N}$ $\mathrm{ha}^{-1}$ and $30 \mathrm{~kg} \mathrm{~K}_{2} \mathrm{O} \mathrm{ha}^{-1}$ ). Urea and $\mathrm{KCl}$ were used as $\mathrm{N}$ and $\mathrm{K}$ sources. Flowering and complete ripening occurred, respectively, at 148 and 179 DAF. The static chamber method was used to collect the gas samples (IAEA, 1992). Gas sampling was conducted once a week on 18 occasions throughout the growing season (GS), beginning at 36 days after sowing (57 DAF) and ending at $176 \mathrm{DAF}$, before the harvest $(10 / 02 / 2009)$, which was carried out with the soil still flooded. The gas samples were analyzed using an Agilent model GC6890 gas chromatograph, equipped with a 6-way valve, and a flame ionization detector (FID). Daily fluxes of $\mathrm{CH}_{4}$ were calculated according to Bayer et al. (2014) and integrated to produce an estimate of the seasonal flow of $\mathrm{CH}_{4}$, representing the accumulated emission for each chamber used. The estimation of the $\mathrm{CH}_{4}$ seasonal emission considered the period from the sowing, although the soil was flooded twenty days earlier, until the complete ripening. The $\mathrm{CH}_{4}$ emission factor was calculated from the division of the seasonal emission (ES) by the total of days of the GS, being expressed in $\mathrm{kg} \mathrm{CH}_{4} \mathrm{ha}^{-1}$ $\mathrm{d}^{-1}$. The partial global warming potential ( $p \mathrm{GWP}$ ), expressed in $\mathrm{kg} \mathrm{CO}_{2}$ eq $\mathrm{ha}^{-1}$, was calculated by multiplying the accumulated emission (seasonal) of $\mathrm{CH}_{4}$ throughout the $\mathrm{GS}$ and its radioactive forcing potential ( $\left.p \mathrm{GWP} \mathrm{CH}_{4}=\mathrm{CH}_{4}{ }^{*} 28\right)$, according to MYHRE et al. (2013). The yield-scaled global warming potential (YpGWP) was also calculated as the ratio of the $p \mathrm{GWP}$ and the yield of rice grains (Bayer et al., 2014). While collecting the gases, the temperatures of the air, the floodwater and the soil at depth of $5 \mathrm{~cm}$ were registered using a five point Full Gauge thermometer. The air temperatures on the inside of each chamber were registered using digital thermometers (MULTI-Thermometer). The soil and water $\mathrm{pH}$ and oxidation-reduction potential (Eh) were measured using a Digimed digital $\mathrm{pH}$-meter. Heights of the plants and of the floodwater were registered. The linear correlation coefficient between these variables and the $\mathrm{CH}_{4}$ flow was determined using the procedure CORR of the SAS program (SAS, 2011). For a comparison of variability between the repetitions, the coefficient of variation $(\mathrm{CV})$ was determined for cumulative $\mathrm{CH}_{4}$ fluxes.
Increasing $\mathrm{CH}_{4}$ flows were observed during the rice tillering period (Figure 1B). Increase in the number of tillers resulted in a greater $\mathrm{CH}_{4}$ transport capacity as a function of the greater density and amount of aerenchyme (KIM et al., 2018). The variety SCS 114 Andosan is characterized by presenting high tillering, which could have contributed to the elevated $\mathrm{CH}_{4}$ flows in this stage. Other emission peaks occurred near the panicle initiation stage (112 DAF) and flowering (148 DAF). GOGOI et al. (2005) also reported the occurrence of a high $\mathrm{CH}_{4}$ flux at the panicle initiation stage, which was attributed to the decomposition of organic carbon in the form of root and leaf exudate and to the increased $\mathrm{CH}_{4}$ transport capacity of the rice plant at this stage. The mean daily $\mathrm{CH}_{4}$ emission was estimated as $616 \mathrm{mg}$ of $\mathrm{CH}_{4} \mathrm{~m}^{-2} \mathrm{~d}^{-1}(\mathrm{CV}: 17.15 \%)$ and the accumulated emission during the season was 93.60 g $\mathrm{CH}_{4} \mathrm{~m}^{-2}$ (CV: $17.15 \%$ ), corresponding to a $\mathrm{CH}_{4}$ emission factor of $6.51 \mathrm{~kg} \mathrm{CH}_{4} \mathrm{ha}^{-1} \mathrm{~d}^{-1}$, which is five times higher than the average indicated by the IPCC (2006), of $1.30 \mathrm{~kg} \mathrm{CH}_{4} \mathrm{ha}^{-1} \mathrm{~d}^{-1}$. The seasonal $\mathrm{CH}_{4}$ emission evaluated in the present study is amongst the highest recorded in the measurement experiments conducted in the country. LIMA et al. (2007) also reported high seasonal $\mathrm{CH}_{4}$ emission values in an experiment carried out in Itajaí, State of Santa Catarina, using the same cultivar (SCS 114 Andosan) under the pre-germinated system, with seasonal emissions accounting $68.84 \mathrm{~g} \mathrm{CH}_{4}$ $\mathrm{m}^{-2}(\mathrm{CV}: 16.76 \%)$ and $138.21 \mathrm{~g} \mathrm{CH}_{4} \mathrm{~m}^{-2}(\mathrm{CV}$ : $8.53 \%$ ) for rice cultivation in mineral and organic soils, respectively. The high $\mathrm{CH}_{4}$ emissions observed in the present study could be probably attributed to the long time under inundation in the pre-germinated system and to the long cycle of the variety, totaling 176 days of inundation from sowing to complete ripening. Impact of the continuous flooding on $\mathrm{CH}_{4}$ emission is well known in the literature (IPCC, 2006; MOTERLE et al., 2013). Moreover, the rice variety used presents high $\mathrm{CH}_{4}$ efflux potential, according to SILVA et al. (2014), although this effect was not evaluated in this study. The correlation analysis between the measured soil, water and meteorological variables and the $\mathrm{CH}_{4}$ fluxes is presented in table 1. Positive and significant correlations were reported between $\mathrm{CH}_{4}$ emission and air and water temperatures and soil temperature at $5 \mathrm{~cm}$ depth. Such relation has registered in numerous studies (WANG et al., 2017, FUMOTO et al., 2018). Data of these variables are presented in the Figure 1C. Plant and floodwater 
Table 1 - Pearson's correlation coefficients and $P$-levels for the linear relationship between $\mathrm{CH}_{4}$ emission and the variables measured.

\begin{tabular}{lcccccccc}
\hline & Tair & Twater & TS5 & pHsoil & pHwater & Eh & Fw_height \\
\hline $\mathrm{CH}_{4}$ & 0.4536 & 0.6021 & 0.5731 & -0.2696 & -0.4295 & -0.3288 & -0.2607 & 0.1156 \\
$P$ & 0.0374 & 0.0082 & 0.0162 & 0.2792 & 0.0753 & 0.1828 & 0.296 \\
\hline
\end{tabular}

Tair: air temperature registered at each sampling; Twater: water temperature; TS5: soil temperature at $5 \mathrm{~cm}$ of depth; Eh: oxy-reduction potential; Fw_height: floodwater depth; Pl_height: plant height.

height, soil and water $\mathrm{pH}$, and oxide-reduction potential showed no significant correlations with $\mathrm{CH}_{4}$ emissions. $p \mathrm{GWP}$ was evaluated as $27.2 \mathrm{Mg}$ $\mathrm{CO}_{2}$ eq ha ${ }^{-1} \mathrm{GS}^{-1}$. Rice production was estimated as $6.8 \mathrm{tha}^{-1}$, the value calculated for YpGWP being 3.9 $\mathrm{kg} \mathrm{CO}_{2}$ eq $\mathrm{kg}^{1}$ of grains, a value much higher than those reported in the literature (Table 2). This study resulted in a $\mathrm{CH}_{4}$ emission factor $\left(6.5 \mathrm{~kg} \mathrm{CH}_{4} \mathrm{ha}^{-1} \mathrm{~d}^{-1}\right)$ for an irrigated rice production system typically used in the state of São Paulo, thus contributing to national

Table 2 - Seasonal $p$ GWP emissions, expressed as $\mathrm{CO}_{2} \mathrm{eq} \mathrm{ha}^{-1}$ season $^{-1}$, grain yield in $\mathrm{Mg} \mathrm{ha}^{-1}$, and seasonal yield-scaled $p \mathrm{GWP}$ in $\mathrm{kg}$ $\mathrm{CO}_{2}$ eq $\mathrm{kg}^{-1}$ grain, from flooded rice cultivation areas in the south and southeast of Brazil under different forms of management.

\begin{tabular}{|c|c|c|c|c|c|}
\hline Source & Local & Management & $\begin{array}{c}\text { Seasonal } \\
p \mathrm{GWP}(\mathrm{Mg} \\
\mathrm{CO}_{2} \mathrm{eq} \mathrm{ha}^{-1} \\
\left.\text { season }^{-1}\right)\end{array}$ & $\begin{array}{c}\text { Grain } \\
\text { yield } \\
\left(\mathrm{Mg} \mathrm{ha}^{-1}\right)\end{array}$ & $\begin{array}{c}\text { Yield-scaled } \\
p \text { GWP } \\
\left(\mathrm{kg} \mathrm{CO}_{2} \text { eq kg-1 }\right. \\
\text { grain) }\end{array}$ \\
\hline \multirow[t]{2}{*}{ BAYER et al. (2014) } & Cachoeirinha, RS & Conventional tillage & $13.3^{(1,3)}$ & $7.9^{(1,3)}$ & $1.8^{(1,3)}$ \\
\hline & & No tillage & 10.3 & 7.7 & 1.4 \\
\hline \multirow[t]{2}{*}{ BAYER et al. (2015) } & Cachoeirinha, RS & Fall tillage & $8.6^{(2,3)}$ & $8.1^{(2,3)}$ & $1.1^{(2,3)}$ \\
\hline & & Spring tillage & $10.9^{(2,3)}$ & $7.7^{(2,3)}$ & $1.4^{(2,3)}$ \\
\hline \multirow[t]{5}{*}{$\begin{array}{l}\text { ZSCHORNACK et } \\
\text { al. (2016) }\end{array}$} & Cachoeirinha, RS & $\mathrm{CF}$ & $10.7^{(4)}$ & $12.0^{(4)}$ & $0.9^{(4)}$ \\
\hline & & II & $6.8^{(4)}$ & $11.8^{(4)}$ & $0.6^{(4)}$ \\
\hline & & $\mathrm{CF}$ & $7.6^{(5)}$ & $10.7^{(5)}$ & $0.7^{(5)}$ \\
\hline & & SII & $2.0^{(5)}$ & $10.4^{(5)}$ & $0.2^{(5)}$ \\
\hline & & FII & $2.6^{(5)}$ & $10.9^{(5)}$ & $0.2^{(5)}$ \\
\hline \multirow[t]{4}{*}{$\begin{array}{l}\text { MOTERLE et al. } \\
\text { (2013) }\end{array}$} & Santa Maria, RS & CWR & 12.8 & 9.3 & 1.4 \\
\hline & & IWR & 9.6 & 9.2 & 1.0 \\
\hline & & CWR & 13.3 & 7.1 & 1.9 \\
\hline & & IWR & 13.2 & 6.8 & 2.0 \\
\hline \multirow[t]{2}{*}{ LIMA et al. (2007) } & Itajaí, SC & PG - Mineral soil & 19.3 & 9.9 & 1.9 \\
\hline & & PG - Organic soil & 38.7 & $4.8^{(6)}$ & $8.0^{(6)}$ \\
\hline \multirow[t]{4}{*}{$\begin{array}{l}\text { EBERHARDT et al. } \\
\text { (2009) }\end{array}$} & Itajaí, SC & PG - Mineral soil & 15.6 & 9.1 & 1.7 \\
\hline & & PG - Organic soil & 17.2 & 6.7 & 2.6 \\
\hline & & PG - Mineral soil & 17.1 & 8.7 & 2.0 \\
\hline & & $\begin{array}{l}\text { Direct seeding in } \\
\text { dry soil }\end{array}$ & 11.5 & 8.7 & 1.3 \\
\hline Current study & Tremembé, SP & PG & 27.2 & 6.8 & 3.9 \\
\hline LIMA et al. (2014) & Pindamonhangaba, SP & Transplanting & $5.2^{(7)}$ & $5.7^{(7)}$ & $0.9^{(7)}$ \\
\hline Not published data & Pindamonhangaba, SP & PG & 8.3 & 7.3 & 1.1 \\
\hline
\end{tabular}

${ }^{1}$ Average of five agricultural years; ${ }^{2}$ Average of seven agricultural years; ${ }^{3} \mathrm{~N}_{2} \mathrm{O}$ emissions included; ${ }^{4} 2009 / 10$ agricultural year; ${ }^{5} 2010 / 11$ agricultural year; ${ }^{6}$ The low rice production was due to the occurrence of diseases; ${ }^{7}$ Average of four agricultural years; CF: Continuous flooding; II: Intermittent irrigation; SII: Sparse intermittent irrigation; FII: Frequent intermittent irrigation; CWR: Continuous water regime; IWR: Intermittent water regime; PG: Pre-germinated. 
and regional databases on $\mathrm{CH}_{4}$ emission factors, which are critical for improving greenhouse gas emission estimates. Result also suggested that further studies should be conducted to investigate the impacts of the pre-germinated system on $\mathrm{CH}_{4}$ emissions under different environmental conditions and varieties, as well as to identify emission mitigation options.

\section{ACKNOWLEDGMENTS}

The authors thank the Financiadora de Estudos e Projetos (FINEP), Brasil, for funding the project CARBOAGRO n. 01.06.0812.00 (FINEP/FIPAI/EMBRAPA).

\section{DECLARATION OF CONFLICT OF INTERESTS}

The authors declare no conflict of interest. The founding sponsors had no role in the design of the study; in the collection, analyses, or interpretation of data; in the writing of the manuscript, and in the decision to publish the results.

\section{AUTHORS' CONTRIBUTIONS}

The authors contributed equally to the manuscript.

\section{REFERENCES}

BAYER, C. et al. Yield-scaled greenhouse gas emissions from flood irrigated rice under long-term conventional tillage and no-till systems in a Humid Subtropical climate. Field Crops Research, v.162, p.60-69, 2014. Available from: <https://www.sciencedirect. com/science/article/pii/S0378429014000781>. Accessed: April 2, 2019. doi: $10.1016 /$ j.fcr.2014.03.015.

BAYER, C. et al. A seven-year study on the effects of fall soil tillage on yield-scaled greenhouse gas emission from flood irrigated rice in a humid subtropical climate. Soil \& Tillage Research, v.145, p.117-125, 2015. Available from: < https://www.sciencedirect. com/science/article/pii/S0167198714001809>. Accessed: Apr. 2, 2019. doi: 10.1016/j.still.2014.09.001.

BRAZIL. Ministry of Science, Technology and Innovation. Third National Communication of Brazil to the United Nations Framework Convention on Climate Change. Brasília: Ministério da Ciência, Tecnologia e Inovação, 2016. 42p. Available from: $<$ https://unfccc.int/resource/docs/natc/branc3es.pdf $>$. Accessed: Apr. $30,2019$.

EBERHARDT, D.S. et al. Emissão de metano em arroz irrigado em Santa Catarina. In: CONGRESSO BRASILEIRO DE ARROZ IRRIGADO, 6, 2009, Porto Alegre. Anais... Porto Alegre, v.1, p.163-166. 2009. Available from: <https://www.embrapa.br/buscade-publicacoes/-/publicacao/578037/emissao-de-metano-emarroz-irrigado-em-santa-catarina $>$. Accessed: Apr. 30, 2019.

EMBRAPA. EMPRESA BRASILEIRA DE PESQUISA AGROPECUÁRIA. Sistema Brasileiro de Classificação de Solos. 3ed. Brasília: EMBRAPA, 2013. 353p.

FUMOTO, T. et al. Revising a process-based biogeochemistry model (DNDC) to simulate methane emission from rice paddy fields under various residue management and fertilizer regimes. Global Change Biology, v.14, p.382-402, 2018 Available from: <https://onlinelibrary.wiley.com/doi/full/10.11 11/j.1365-2486.2007.01475.x>. Accessed: Apr. 24, 2019. doi: 10.1111/j.1365-2486.2007.01475.x.

GOGOI, N.et al. Methane emission characteristics and its relations with plant and soil parameters under irrigated rice ecosystem of northeast India. Chemosphere, v.59, p.16771684, 2005. Available from: <https://www.sciencedirect. com/science/article/pii/ S0045653504011178?via\%3Dihub>. Accessed: Apr. 17, 2019 . doi: 10.1016/j. chemosphere.2004.11.047.

IAEA. Manual on measurement of methane and nitrous oxide emissions from agriculture, Ch.3, INIS Clearinghouse, International Atomic Energy Agency, Vienna, 1992.

IPCC. 2006 IPCC Guidelines for National Greenhouse Gas Inventories. Eggleston, H.S. et al. (eds). IGES, Japan, v.4, ch.5, 2006. Available from: <https://www.ipcc-nggip.iges.or.jp/ public/2006gl/pdf/4 Volume4/V4 05 Ch5 Cropland.pdf $>$. Accessed: Apr. 17, 2019.

KIM, W.-J. et al. Correlation between Methane $\left(\mathrm{CH}_{4}\right)$ Emissions and Root Aerenchyma of Rice Varieties. Plant Breeding and Biotechnology, Suwon, v.6, n.4, p.381-390, 2018. Available from: $<$ https://doi.org/10.9787/PBB.2018.6.4.381>. Accessed: Apr. 2, 2019. doi: 10.9787/PBB.2018.6.4.381.

LIMA, M.A. et al. Emissão de metano em lavouras de arroz irrigado sob sistema pré-germinado. In: CONGRESSO BRASILEIRO DE ARROZ IRRIGADO, 5., 2007, Pelotas. Anais... Pelotas: Embrapa Clima Temperado, 2007. v.1. p.417-419, 2007. Available from: $<$ https://www.embrapa.br/busca-de-publicacoes/-/ publicacao/15997/emissao-de-metano-em-lavouras-de-arrozirrigado-sob-sistema-pre-germinado>. Accessed: April, 17, 2019.

LIMA, M.A. et al. Methane emissions in flooded rice cultivation. In: BODDEY, R. M. et al. (Ed.). Carbon stocks and greenhouse gas emissions in Brazilian agriculture. Brasília, DF: Embrapa, 2014. Chapter 6.

MOTERLE, D.F. et al. Methane efflux in rice paddy field under different irrigation managements. Revista Brasileira de Ciência do Solo, v.37, p.431-437, 2013. Available from: <http://dx.doi. org/10.1590/S0100-06832013000200014>. Accessed: Apr. 2, 2019. doi: 10.1590/S0100-06832013000200014.

MYHRE, G. et al. Anthropogenic and Natural Radiative Forcing. In: Climate Change 2013: The Physical Science Basis. [Stocker, T.F. et al. (eds.)]. Cambridge University Press, Cambridge, 2013.

SAS INSTITUTE INC. SAS/STAT ${ }^{\circledR} 9.3$ User's Guide. Cary, NC: SAS Institute Inc., 2011.

SILVA, L.S. et al. Dinâmica da emissão de metano em solos sob cultivo de arroz irrigado no sul do Brasil. Revista Brasileira de Ciência do Solo, v.35, p.473-481, 2011. Available from: $<\mathrm{http}: / /$ dx.doi.org/10.1590/S0100-06832011000200016>. Accessed: Apr. 17, 2019.

SILVA, L.S. et al. The impact of different rice cultivars on soil methane emissions. In: Sustainable agroecosystems in climate mitigation. Ed. Oelbermann, M., Wageningen Academic Publishers, Wageningen, 2014, p. 87-98. 
SILVA, F. C. da (Ed.). Manual de análises químicas de solos, plantas e fertilizantes. 2. ed. Brasília, DF: Embrapa Informação Tecnológica; Rio de Janeiro: Embrapa Solos, 2009. 627 p.

WANG et al. Factors Related with $\mathrm{CH}_{4}$ and $\mathrm{N}_{2} \mathrm{O}$ Emissions from a Paddy Field: Clues for Management implications. PLoS ONE, v.12, n.1, 2017. Available from: <https://journals.plos.org/plosone/ article?id=10.1371/journal.pone.0169254 $>$. Accessed: Apr. 24, 2019. doi: 10.1371/journal.pone.0169254.
ZSCHORNACK etal. Mitigation of yield-scaled greenhouse gas emissions in subtropical paddy rice under alternative irrigation systems. Nutrient Cycling Agroecosystems, v.105, p.61-73, 2016. Available from: $<$ https:// doi.org/10.1007/s10705-016-9775-0>. Accessed: Jul. 11, 2019.

ZSCHORNACK et al. Mitigation of methane and nitrous oxide emissions from flood-irrigated rice by no incorporation of winter crop residues into the soil. Revista Brasileira de Ciência do Solo, v.35, n.2, p.623-634, 2011. Available from: <http://dx.doi. org/10.1590/S0100-06832011000200031>. Accessed: Jul. 11, 2019. 


\section{Erratum}

In the article "Methane emission from a flooded rice field under pre-germinated system" published in Ciência Rural, volume 49, number 11, DOI http://dx.doi.org/ 10.1590/0103-8478cr20190336.

\section{In the ABSTRACT, where we read:}

The study showed high seasonal emission of methane $\left(\mathrm{CH}_{4}\right)$ for the studied area, probably due to the long flooding period. It was estimated the $\mathrm{CH}_{4}$ emission factor (6.51 $\mathrm{kg} \mathrm{CH}_{4} \mathrm{ha}^{-1} \mathrm{dia}^{-1}$ ), the partial global warming potential (pGWP, $27.2 \mathrm{Mg} \mathrm{CO}_{2} \mathrm{eq}$ growing season $^{-1} \mathrm{ha}^{-1}$ ) and the yield-scaled pGWP (YpGWP, $3.9 \mathrm{~kg} \mathrm{CO} \mathrm{CO}_{2} \mathrm{~kg}$ grain).

\section{Read:}

The study showed high seasonal emission of methane $\left(\mathrm{CH}_{4}\right)$ for the studied area, probably due to the long flooding period. It was estimated the $\mathrm{CH}_{4}$ emission factor (6.2 $\mathrm{kg} \mathrm{CH}_{4} \mathrm{ha}^{-1} \mathrm{dia}^{-1}$ ), the partial global warming potential (pGWP, $26.2 \mathrm{Mg} \mathrm{CO} \mathrm{CO}_{2} \mathrm{eq}$ growing season ${ }^{-1} \mathrm{ha}^{-1}$ ) and the yield-scaled pGWP (YpGWP, 3.9 kg CO2eq kg grain).

\section{In the RESUMO, where we read:}

Foi estimado o fator de emissão de $\mathrm{CH}_{4}\left(6,51 \mathrm{~kg} \mathrm{CH}_{4} \mathrm{ha}^{-1} \mathrm{dia}^{-1}\right)$, o potencial de aquecimento global parcial (PAGp, 27,2 $\mathrm{Mg} \mathrm{CO}_{2} \mathrm{eq}$ estação de crescimento $^{-1}$ ha $^{-1}$ ) e o PAGp escalonado pelo rendimento (R) de grãos (PAGpR, 3,9 kg CO $\mathrm{CO}_{2} \mathrm{eq} \mathrm{kg}{ }^{-1}$ grão).

\section{Read:}

Foi estimado o fator de emissão de $\mathrm{CH}_{4}\left(6,2 \mathrm{~kg} \mathrm{CH} \mathrm{Ch}^{-1} \mathrm{dia}^{-1}\right)$, o potencial de aquecimento global parcial (PAGp, 26,2 Mg CO2eq estação de crescimento ${ }^{-1}$ ha $^{-1}$ ) e o PAGp escalonado pelo rendimento (R) de grãos (PAGpR, 3,9 kg CO $\mathrm{CO}_{2} \mathrm{~kg}^{-1}$ grão). 


\section{In the text, where we read:}

The mean daily $\mathrm{CH}_{4}$ emission was estimated as $616 \mathrm{mg}$ of $\mathrm{CH}_{4} \mathrm{~m}^{-2} \mathrm{~d}^{-1}(\mathrm{CV}: 17.15 \%)$ and the accumulated emission during the season was $93.60 \mathrm{~g} \mathrm{CH}_{4} \mathrm{~m}^{-2}(\mathrm{CV}: 17.15 \%)$, corresponding to a $\mathrm{CH}_{4}$ emission factor of $6.51 \mathrm{~kg} \mathrm{CH}_{4} \mathrm{ha}^{-1} \mathrm{~d}^{-1}$, which is five times higher than the average indicated by the IPCC (2006), of $1.30 \mathrm{~kg} \mathrm{CH}_{4} \mathrm{ha}^{-1} \mathrm{~d}^{-1}$.

\section{Read:}

The mean daily $\mathrm{CH}_{4}$ emission was estimated as $616 \mathrm{mg}$ of $\mathrm{CH}_{4} \mathrm{~m}^{-2} \mathrm{~d}^{-1}(\mathrm{CV}: 17.15 \%)$ and the accumulated emission during the season was $93.60 \mathrm{~g} \mathrm{CH}_{4} \mathrm{~m}^{-2}(\mathrm{CV}: 17.15 \%)$, corresponding to a $\mathrm{CH}_{4}$ emission factor of $6.2 \mathrm{~kg} \mathrm{CH}_{4} \mathrm{ha}^{-1} \mathrm{~d}^{-1}$, which is five times higher than the average indicated by the IPCC (2006), of $1.30 \mathrm{~kg} \mathrm{CH}_{4} \mathrm{ha}^{-1} \mathrm{~d}^{-1}$.

\section{In the text, where we read:}

Data of these variables are presented in the Figure 1C. Plant and floodwater height, soil and water $\mathrm{pH}$, and oxide-reduction potential showed no significant correlations with $\mathrm{CH}_{4}$ emissions. pGWP was evaluated as $27.2 \mathrm{Mg} \mathrm{CO}_{2} \mathrm{eq} \mathrm{ha}{ }^{-1} \mathrm{GS}^{-1}$. Rice production was estimated as $6.8 \mathrm{t} \mathrm{ha}^{-1}$, the value calculated for YpGWP being $3.9 \mathrm{~kg} \mathrm{CO}_{2} \mathrm{eq} \mathrm{kg}^{1}$ of grains, a value much higher than those reported in the literature (Table 2). This study resulted in a $\mathrm{CH}_{4}$ emission factor $\left(6.5 \mathrm{~kg} \mathrm{CH}_{4} \mathrm{ha}^{-1} \mathrm{~d}^{-1}\right)$ for an irrigated rice production system typically used in the state of São Paulo, thus contributing to national and regional databases on $\mathrm{CH}_{4}$ emission factors, which are critical for improving greenhouse gas emission estimates.

\section{Read:}

Data of these variables are presented in the Figure 1C. Plant and floodwater height, soil and water $\mathrm{pH}$, and oxide-reduction potential showed no significant correlations with $\mathrm{CH}_{4}$ emissions. pGWP was evaluated as $26.2 \mathrm{Mg} \mathrm{CO}_{2} \mathrm{eq} \mathrm{ha}{ }^{-1} \mathrm{GS}^{-1}$. Rice production was estimated as $6.8 \mathrm{t} \mathrm{ha}^{-1}$, the value calculated for YpGWP being $3.9 \mathrm{~kg} \mathrm{CO}_{2} \mathrm{eq} \mathrm{kg}^{-1}$ of grains, a value much higher than those reported in the literature (Table 2). This study resulted in a $\mathrm{CH}_{4}$ emission factor $\left(6.2 \mathrm{~kg} \mathrm{CH}_{4} \mathrm{ha}^{-1} \mathrm{~d}^{-1}\right)$ for an irrigated rice production system typically used in the state of São Paulo, thus contributing to national and regional databases on $\mathrm{CH}_{4}$ emission factors, which are critical for improving greenhouse gas emission estimates. 